\title{
Supplementing With Vitamin C the Diet of Honey Bees Parasitized With Varroa destructor: Effect on Carbohydrate Metabolism
}

\author{
Elżbieta Łopieńska-Biernat ${ }^{1}$, Marek Farjan ${ }^{1}$, Krystyna Żółtowska ${ }^{1}$, Małgorzata Dmitryjuk ${ }^{1}$, \\ Zbigniew Lipiński ${ }^{2} \&$ Ewa Szypulska ${ }^{1}$ \\ ${ }^{1}$ Department of Biochemistry, Faculty of Biology and Biotechnology, University of Warmia and Mazury in \\ Olsztyn, Olsztyn, Poland \\ ${ }^{2}$ Institute of Animal Reproduction and Food Research, The Polish Academy of Sciences, Olsztyn, Poland \\ Correspondence: Elżbieta Łopieńska-Biernat, Department of Biochemistry, Faculty of Biology and Biotechnology, \\ University of Warmia and Mazury in Olsztyn, Oczapowskiego 1A, 10-957 Olsztyn, Poland. Tel: 48-895-352-015. \\ E-mail: ela.lopienska@uwm.edu.pl
}

Received: October 10, 2018

Accepted: November 7, 2018

Online Published: January 15, 2019

doi:10.5539/jas.v11n2p1

URL: https://doi.org/10.5539/jas.v11n2p1

The research financed by Faculty of Biology and Biotechnology (12.610.012.300).

\begin{abstract}
The most profound decrease in the number of honey bee (Apis mellifera carnica) colonies is observed after winter. This study evaluates the effect of vitamin C (ascorbic acid, AA) supplementation in wintering colonies of honey bees naturally infested with the parasitic mite Varroa destructor on total carbohydrate content, glycogen, trehalose, glucose and fructose concentrations, and the activity of amylase and disaccharidases in a developing worker brood. The severity of the infestation was lower (1.18 \pm 0.6 of mites per bee) in bees whose diet were supplemented with vitamin C (group AA) than in the control group (C) (1.32 \pm 0.56 mites/bee). Glycogen and trehalose levels and the activity of $\alpha$-amylase, glucoamylase and trehalase were significantly higher in newly emerged workers from group AA. The results of the study indicate that vitamin $\mathrm{C}$ in the diet of honey bees moderately reduces infestation levels and might improve selected indicators of carbohydrate metabolism in infested workers and thus improves the condition of apiaries.
\end{abstract}

Keywords: Apis mellifera carnica, carbohydrates, $\alpha$-glycosidases, Varroa destructor, vitamin C

\section{Introduction}

The honey bee (Apis mellifera) is a social insect that plays a highly significant role in natural ecosystems and the economy. Honeybees pollinate more than $80 \%$ of plants and supply highly valuable products such as honey, beeswax, royal jelly and propolis (Burgett et al., 2004). Recent years witnessed a decrease in the number of bee colonies, in North America and selected European countries (Van der Zee et al., 2012; Van Engelsdorp \& Meixner, 2010). Varroa destructor is believed to be one of the key factors responsible for the loss of honey bee populations (Cornman et al., 2012; Danidat et al., 2012). This parasitic mite feeds on the hemolymph of capped brood and adult honey bees. The varroasis contributes to weight loss and a reduction in protein and carbohydrate content in bees (Sammataro et al., 2000; Bowen-Walker \& Gunn, 2001; Duay et al., 2003; Źółtowska et al., 2005; Kuster et al., 2014). One of the most harmful effects of this disease on immunology response in bees is spreading the pathogens like bacteria, viruses and fungi by mites (Kuster et al., 2014; Gliński \& Jarosz, 1988, 1992; Yang \& Cox-Foster, 2005; Francis et al., 2013). Parasitic infestations are controlled mechanically or with the use of natural organic substances and synthetic acaricides (Francis et al., 2013). Synthetic acaricides are initially highly effective, but Varroa mites quickly develop resistance to those pesticides (Maharaj, 2011). Synthetic acaricides became less effective with time, and they contaminated the environment and bee products (Wu et al., 2011; Ostiguy \& Eitzer, 2014). Attempts are being made to control the spread of pathogenic mites with natural compounds such as organic acids and essential oils (Underwood \& Currie, 2003; Harz et al., 2010; Rozenkranz et al., 2010). In our previous work, symptoms of oxidative stress were observed in infested drone prepupae (Lipiński \& Żółtowska, 2005). Those findings prompted a new study into the effects of ascorbic acid (AA), a compound with antioxidant and immune-boosting properties, on the spread of varroasis and nosemosis in bees 
(Benzzie, 2003; Mishra, 2007; Glavinic et al., 2017). Ascorbic acid was administered to bees in the form of commercially available vitamin $\mathrm{C}$. The results indicate that dietary supplementation with AA delivers health benefits for both healthy and infested bees, as well during spring and winter. The supplementation reduced winter losses and the severity of varroasis in the analyzed population. Ascorbic acid strengthened the antioxidant system, increased body weight and protein level in newly hatched bees (Andi \& Ahmadi, 2014; Farjan et al., 2012, 2015).

Carbohydrates are the main source of energy for bees (Blatt \& Roces, 2001; Hrassing \& Crailsheim, 2005; Broschneider \& Crailsheim, 2010), and therefore the effect of vitamin C on carbohydrate metabolism in healthy bees was also studied (Farjan et al., 2015). The parameters of carbohydrate metabolism were compared in infested bees whose diet was and were not supplemented with vitamin C. In the following stage of the study, we investigated whether with vitamin $\mathrm{C}$ would have a similar effect on colonies naturally infested with $V$. destructor. We have shown that ascorbic acid increased body weights, glycogen and trehalose concentrations and the activity of enzymes that break down those carbohydrates. Similarly, to our previous study (Farjan et al., 2014), the prevalence and the severity of varroasis were reduced in bees receiving vitamin C. The results of those experiments are discussed in this article.

\section{Materials and Methods}

The experimental material was collected from an experimental apiary situated $20 \mathrm{~km}$ from Olsztyn (N 53,8352, E 20,3450), from eight colonies of honey bee (A. mellifera carnica) headed by sister queens and naturally infested with $V$. destructor. The colonies were established at the same time. They were in identical age, and they were kept in the same private stationary apiary under identical conditions. Four of the eight colonies constituted the control group $(\mathrm{C})$ without ascorbic acid supplementation, whereas the remaining four colonies were fed with vitamin $\mathrm{C}$ and constituted the experimental group (AA). The first feeding of wintering bees took place in September 2007. Both groups received sucrose syrup, composed of refined sugar dissolved in water $(3: 1)$, in the amount of $11 \mathrm{~kg}$ per colony, but the syrup administered to experimental group (AA) was supplemented with ascorbic acid (Vitamin C, Biofactor, Poland) in the amount of $1.8 \mathrm{~g}$ per $\mathrm{kg}$ of syrup. The second feeding took place on 1 March 2008 according to the same protocol. Due to low temperatures in the spring of 2008, comb sections were collected from all colonies on 1 May 2008, immediately before the growing season. Two combs from each colony were transported to a laboratory, and within 40 minutes after arrival, the brood was carefully isolated from capped cells. The infestation level of colonies was assessed after wintering by analyzing individuals from capped cells and newly emerged workers from 2 combs in each colony from group $C$ and group AA. The number of examined worker bees (in various stages of development), including newly emerged imagines, was $n=12,500$ in group $C$ and $n=12,500$ in group AA. Those numbers were used to calculate prevalence, the percentage of infested worker bees, and the severity of infestations, the average number of mites colonizing one infested bee. The brood was classified based on morphological features characteristic for different stages of development proposed by Jay $(1962,1963)$. Nine developmental stages were identified: 6-day-old larvae (L6) (counting from the moment of hatching), spinning larvae (L7), prepupae (PP), pupae with white eyes (P1), pupae with pale-pink eyes (P2), pupae with pink eyes (P3), pupae with brown eyes and a yellow thorax (P4), and pupae with black eyes and a dark thorax (P5). Newly emerged workers (A) were also examined. 135 samples representing all the examined development stages were randomly collected for each group- $\mathrm{C}$ and AA (15 samples for each development stage). Each sample consisted of three individuals. Every isolated brood sample was carefully rinsed in $0.9 \% \mathrm{NaCl}$, dried on filter paper and weighed. The material was stored at $-70{ }^{\circ} \mathrm{C}$ until further analyses.

Immediately before the analysis, brood samples were homogenized (Omni Tissue Homogenizer, TH) in $0.9 \%$ $\mathrm{NaCl}$ at $0.1 \mathrm{~g}$ of fresh body weight per $1 \mathrm{ml}$ of the solution, for 2 minutes, at $5000 \mathrm{rpm}$, in an ice bath. The homogenate was centrifuged for 10 minutes at $15000 \times g$, at $4{ }^{\circ} \mathrm{C}$. The supernatant below the fatty layer was collected for analysis. Before the assay, the extract was diluted 5 times with $0.9 \% \mathrm{NaCl}$.

\subsection{Carbohydrate Content}

Total carbohydrate content was determined by the anthrone method (Morse, 1947), and glycogen concentrations - by the method proposed by Sölling and Essman (1975). Trehalose, sucrose, glucose and fructose content was measured by high-performance liquid chromatography (HPLC) in accordance to the method described by Farjan et al. (2015). The results were expressed in terms of $\mathrm{mg}$ per $100 \mathrm{mg}$ of fresh body weight (BW).

\subsection{Enzyme Activity}

The activity of $\alpha$-amylase was determined based on the method described by Caraway (1959), and it was expressed by the amount (mg) of starch decomposed during 10 minutes of incubation at $35^{\circ} \mathrm{C}$ in terms of $1 \mathrm{mg}$ 
of protein. Glucoamylase activity was determined with $5 \%$ aqueous glycogen solution as the substrate. The activity of disaccharidases (trehalase, maltase and sucrase) was measured by the method proposed by Dahlquist et al. (1968) using $0.15 \mathrm{M}$ solutions of trehalose, maltose and sucrose as substrates, respectively. Glucose released during disaccharidase and glucoamylase reactions was determined using with the Liquick Cor-GLUCOSE Kit (Cormay, Poland) for enzymatic determination of glucose. Enzymatic activity was expressed by the amount of released glucose in terms of $1 \mathrm{mg}$ of protein. Protein content was determined by Bradford (1976) method. The extract was thrice diluted with $0.9 \% \mathrm{NaCl}$ before the determination of protein content.

\subsection{Statistical Analysis}

Statistical analyses were conducted using the Statistica software package (Statsoft, V. 12.0). Statistical analysis between the number of infested and uninfested bees in the groups $C$ (control) and AA (supplemented with ascorbic acid) was made with Pearson's chi-squared test with Yates's correction for continuity. The results were considered statistically significant at $p<0.0001$. Statistically significant differences at $p \leq 0.05$ for biochemical analyzes were determined with the use of one-way ANOVA with Tukey's test for features with normal distribution (Shapiro-Wilk's test) and with Kruskal-Wallis's test for features with abnormal distribution (Shapiro-Wilk's test).

\section{Results}

\subsection{Parasitological Analysis}

Prevalence, the percentage of infested individuals, was calculated based on the pooled sample of all individuals in one group $(\mathrm{n}=12500)$. It was determined at $15.6 \%(1950$ infested bees $)$ in group $\mathrm{C}$ and $10.05 \%(1256$ infested bees) in group AA. Analysis showed that degree of the infestation rate in the C group is 0.15 and for the AA group is 0.10 . The difference between these indices was statistically significant $\mathrm{p}<0.0001$ ( $\mathrm{n} \mathrm{C}=12500, \mathrm{n}$ $\mathrm{AA}=12500$ ). The intensity of infestation, the average number of mites colonizing one infested individual, was determined at 1.32 mites/bee in group C and 1.18 mites/bee in group AA. One (most frequently) to 4 (rarely) $V$. destructor mites per cell were identified. The results of Pearson's chi-squared test with Yates's correction of the number of infested bees for uninfested bees in C and AA groups were 160 and40, respectively, where $\mathrm{df}=1$ and $\mathrm{p}<0.0001$. The risk of infestation of bees in the AA group and the risk of infestation in the $\mathrm{C}$ group was 0.737 and 0.838 respectively ( $95 \%$ confidence interval OR coefficient). Then the odds ratio was OR $=0.792,95 \%$ c. 1 . This ratio indicates that the chance of infestation in group AA was 20-25\% lower than in group C.

\subsection{Body Weight}

Dietary supplementation did not induce changes in the weight of infested brood (Table 1). Only newly emerged bees were heavier in group AA than in group C.

\subsection{Protein Content}

Dietary supplementation had no significant effect on protein content. Beginning from the pupal stage, protein content was somewhat higher in group AA, in stage P5 and A, but differences between group means were not statistically significant (Table 1). 
Table 1. Body weights and protein concentrations in the ontogeny of honeybee worker brood infested with Varroa destructor $($ mean $\pm \mathrm{SD})$

\begin{tabular}{llllll}
\hline & \multicolumn{2}{c}{ Body weight (BW) $(\mathbf{m g})$} & & \multicolumn{2}{c}{ Protein concentration (mg/100mg BW) } \\
\cline { 2 - 3 } \cline { 5 - 5 } Stage* & Control group (C) & $\begin{array}{c}\text { Group supplemented } \\
\text { with ascorbate (AA) }\end{array}$ & & Control group (C) & $\begin{array}{l}\text { Group supplemented } \\
\text { with ascorbate (AA) }\end{array}$ \\
\hline L6 & $166.4 \pm 11.2$ & $152.3 \pm 13.2$ & & $18.0 \pm 0.4$ & $16.9 \pm 0.3$ \\
L7 & $180.1 \pm 6.2$ & $175.2 \pm 10.1$ & & $15.9 \pm 0.1$ & $15.8 \pm 0.5$ \\
PP & $145.7 \pm 10.1$ & $139.8 \pm 8.7$ & & $18.1 \pm 2.1$ & $18.2 \pm 2.5$ \\
P1 & $136.9 \pm 8.9$ & $133.3 \pm 9.7$ & & $18.5 \pm 1.5$ & $19.6 \pm 1.4$ \\
P2 & $127.0 \pm 9.7$ & $124.3 \pm 10.1$ & & $17.4 \pm 0.5$ & $17.9 \pm 0.9$ \\
P3 & $120.0 \pm 10.1$ & $124.0 \pm 6.5$ & $15.6 \pm 1.5$ & $18.2 \pm 2.6$ \\
P4 & $118.7 \pm 8.7$ & $123.9 \pm 8.9$ & $13.5 \pm 1.3$ & $13.9 \pm 1.4$ \\
P5 & $115.1 \pm 9.7$ & $122.37 \pm 8.9$ & $11.3 \pm 2.2$ & $13.7 \pm 1.3$ \\
A & $101.2 \pm 8.1$ & $119.11 \pm 7.5^{\text {a }}$ & & $10.7 \pm 1.9$ & $13.3 \pm 1.6$ \\
\hline
\end{tabular}

Note. *six-day-old larvae (L6), spinning larvae (L7), prepupae (PP), pupae with white eyes (P1), pale-pink eyes (P2), pink eyes (P3), brown eyes and a yellow thorax (P4), pupae with dark eyes and a dark thorax (P5), newly emerged imagines(A). ${ }^{a}$ letter indicate significant differences between stage means in groups $\mathrm{C}$ and AA ( $\mathrm{p} \leq$ $0.05)$.

\subsection{Carbohydrate Content}

Total carbohydrate content decreased steadily in successive developmental stages in group C. Fluctuations were noted in group AA, but differences between groups, excluding L7 larvae, were statistically significant (Figure 1A). Similar trend was noted in an analysis of glycogen concentration (Figure 1B). Glycogen levels were significantly higher in group AA than in group C only in three development stages: L7, P3 and imagines. Trehalose content was similar in most developmental stages in both groups, excluding stages P3 and A where trehalose concentrations were higher in group AA than in group C (Figure 1B).
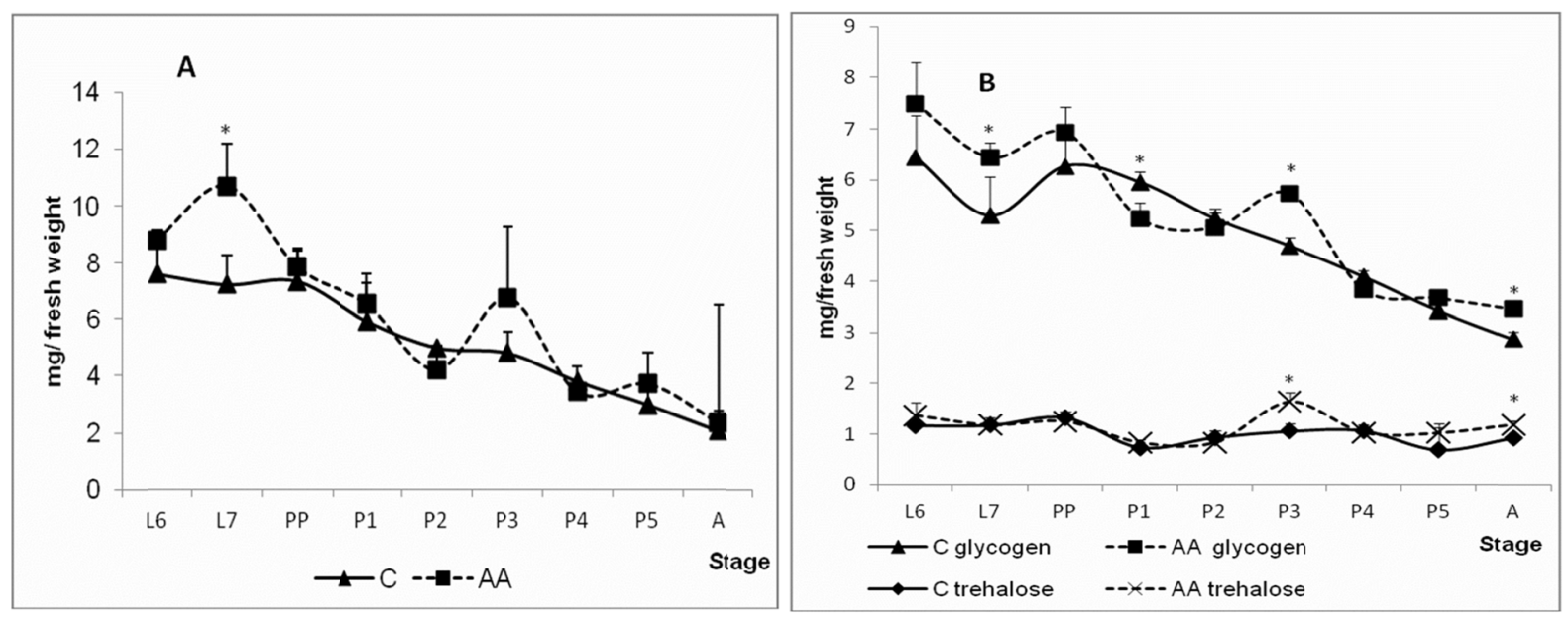

Figure 1. Sugar content in developing worker brood of honey bees infested with Varroa destructor $[\mathrm{mg} / 100 \mathrm{mg}$ fresh weight]. A: Total sugar concentrations; B: Concentrations of glycogen and trehalose. C: Control group (without supplementation); AA: group supplemented with vitamin C. Stages: L6: six-day-old larvae, L7: spinning larvae, PP: prepupae, P1: pupae with white eyes, P2: pupae with pale-pink eyes, P3: pupae with pink eyes, P4: pupae with brown eyes and a yellow thorax, P5: pupae with dark eyes and a dark thorax, A newly emerged imago

Note. ${ }^{*}$ Significant difference between means in groups $\mathrm{C}$ and $\mathrm{AA}(\mathrm{P} \leq 0.05)$.

Sucrose was identified in a small number of samples, and those results were disregarded. Glucose levels were five- to six-fold lower than fructose concentrations in larvae from both groups (Figure 2). A rapid drop in the 
concentration of glucose (Figure 2A), but not fructose (Figure 2B), was observed in prepupae. Until stage P3, glucose levels were higher in the brood of group AA than group $\mathrm{C}$, but differences in mean values were statistically significant only in stages L6, P2 and P3. The above trend was reversed in successive stages of development, but no significant differences between group means were noted due to high standard deviations (Figure 2A). Fructose concentration were high and similar in both groups between stages L7 and P3. In stages PP, $\mathrm{P} 4$ and A, significantly higher fructose levels were noted in group C than in group AA (Figure 2B).
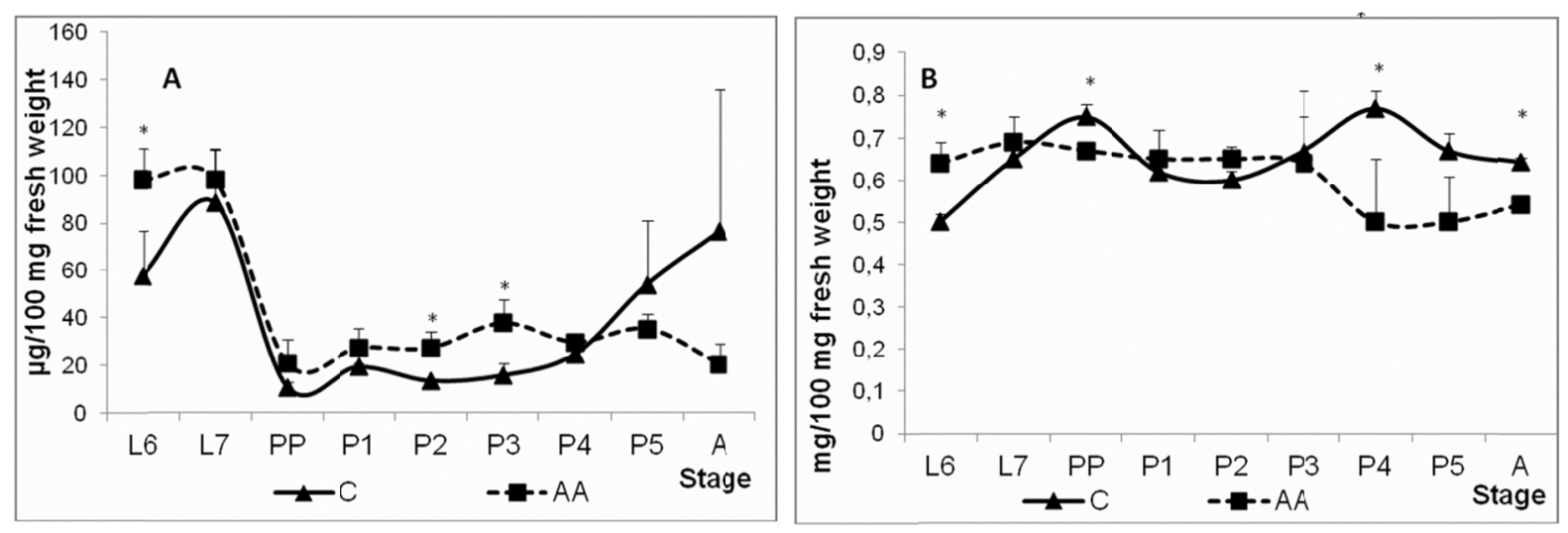

Figure 2. Sugar content in developing worker brood of honey bees infested with Varroa destructor $[\mathrm{mg} / 100 \mathrm{mg}$ Fresh Weight]. A: Glucose concentrations [mg/100 mg fresh weight]; B: Fructose concentrations [mg/100 mg Fresh Weight]. Explanation as in Figure 1

\subsection{Enzyme Activity}

The activity of both amylases is presented in Figure 3. Significant fluctuations in $\alpha$-amylase activity were noted in group AA. In both groups, the activity of $\alpha$-amylase is significantly differed in most developmental stages, excluding PP, P1 and P4. The discussed enzyme was also significantly more active in newly emerged imagines in group AA (Figure 3A). Unlike, $\alpha$-amylase and glucoamylase activity was very low in stage L6, and it increased in stage L7, particularly in group C (Figure 3B). Glucoamylase levels were low or very low in prepupae and in successive developmental stages of both groups. Trace activities of glucoamylase were found in group AA until stage P3 (Figure 3B), and they were significantly lower than in group C. The above trend was reversed in stage P5 and, thus, glucoamylase activity in imagines was higher in group AA than in group C (Figure 3B).
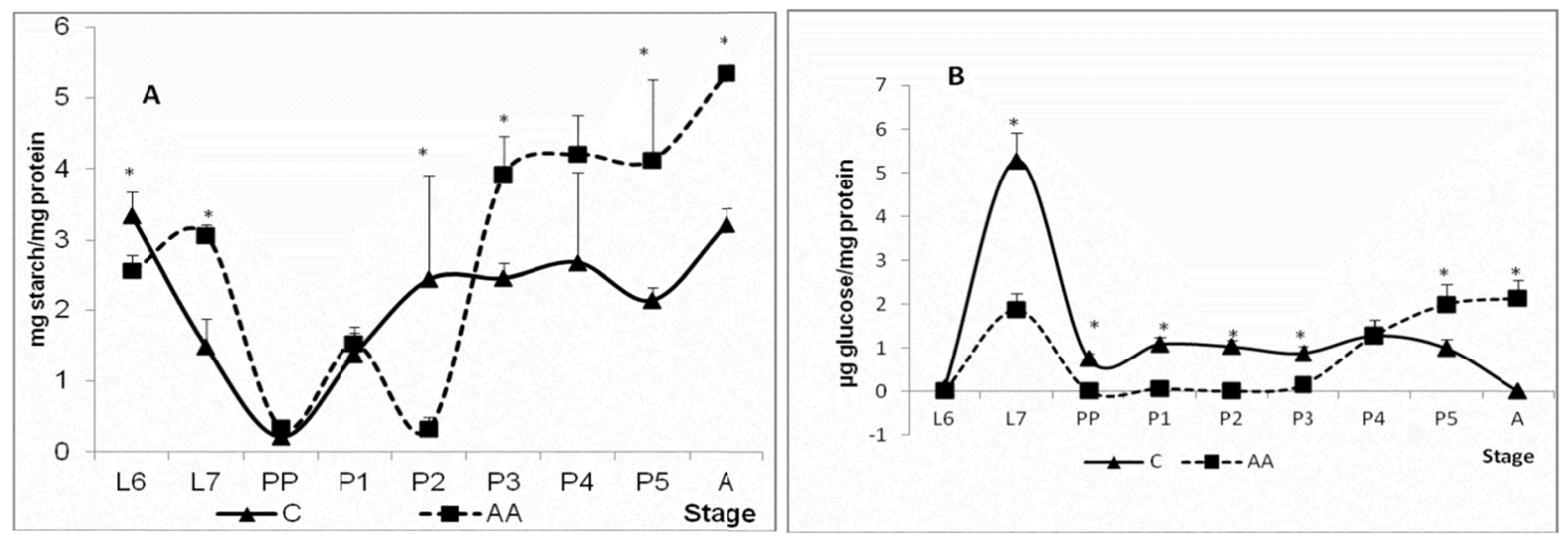

Figure 3. Amylase activities in developing worker brood of honey bees infested with Varroa destructor [mg/100 $\mathrm{mg}$ fresh weight]. A: Alpha-amylase [mg starch/mg protein]; B: Glucoamylase [ $\mu$ g glucose/mg protein].

Explanation as in Figure 1 
Dietary supplementation with vitamin C induced significant differences in disaccharidases activity between most development stages group $\mathrm{C}$ and group AA (Figure 4). Significant differences were noted in the activity of disaccharidases: trehalase - in stages L7, PP, P5 and A (Figure 4A), maltase - in stages L7, PP, P2 and P3 (Figure 4B), and sucrase - in stages L6 and P2 (Figure 4C). In the final stages of development, disaccharidases activity increased in both groups and was highest in newly emerged worker bees. The only exception was noted in group $C$ where trehalase activity was lower in imagines than in P5 pupae (Figure 4A).
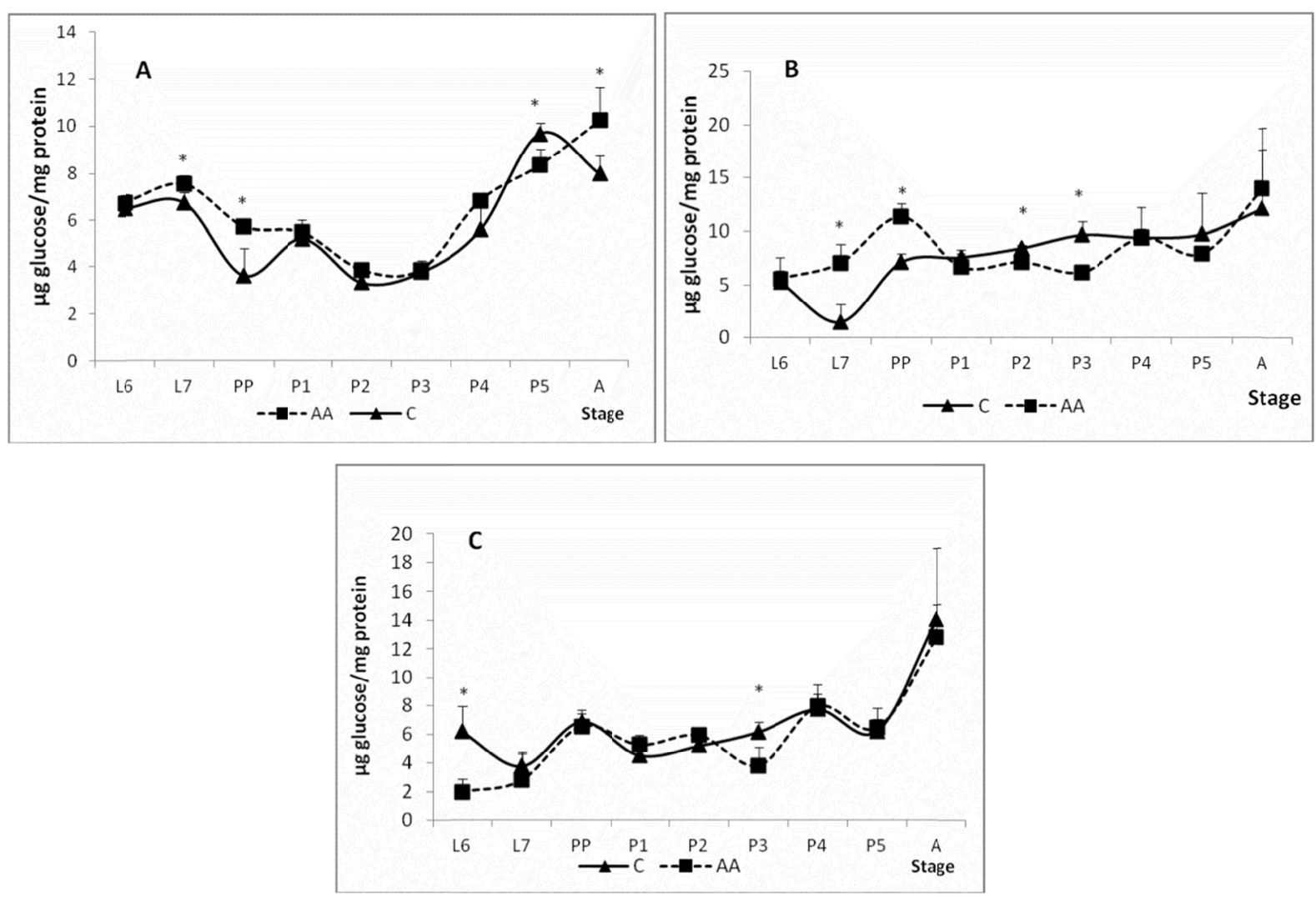

Figure 4. Disaccharidase activities in developing worker brood of honey bees infested with Varroa destructor $[\mu \mathrm{g}$ glucose/mg protein]. A: Trehalase; B: Maltase; C: Sucrase. Explanation as in Figure 1

\section{Discussion}

The health of bee colonies is a crucial factor from the biological and economic point of view, in early spring before bees begin to collect nectar and pollen. Attempts are being made to increase and maintain a colony's vitality during that period. To achieve that goal, some beekeepers supplement bee diets to develop and maintain colonies with optimal population size (Standifer, 1980). Vitamin supplements are recommended, but the effects of vitamin supplementation in the diets of wintering bees have been scantily researched (Black, 2006). Loper et al. (1980) demonstrated a rapid decrease in the vitamin C content of bee bread stored in the hive. In winter, food reserves are not supplemented with fresh pollen or nectar, the main sources of vitamin $\mathrm{C}$ for bees. Insects are unable to synthesize endogenous AA which, together with the progressing drop in AA levels in bee bread, can lead to a vitamin C deficiency (Briggs, 1962; Loper et al., 1980; Kramer \& Seib, 1982). Vitamin C deficiency has serious consequences for the brood, and it is associated with abnormalities in cuticular sclerotization and retarded development of post pharyngeal glands (Kramer \& Seib, 1982). The results reported by Loper et al. (1980) indicate that supplementation of bee diets with vitamin C in winter months delivers positive effects. By contrast, Herbert et al. (1985) did not observe any significant effects of vitamin C supplementation on brood production or the weight of healthy bees. The latter results are consistent with our previous findings. Ascorbic acid administered to bees in winter and early spring had no significant impact on the weight of healthy brood and newly emerged workers (Farjan et al., 2012). However, in colonies infested with $V$. destructor, vitamin C supplementation significantly increased the weight of adult individuals and reduced infestation rates (Farjan et al., 2014). Similar results were noted in this study. Group AA was less affected by varroasis than bees in control 
group. In this study and in our previous research, protein content was higher in P5 pupae and in newly emerged bees in group AA than in group C, therefore, the trend change was identical in both cases. In our previous study (Farjan et al., 2012), the differences between means were statistically significant, because standard deviation was lower than in the present study.

According to Contzen et al. (2004), low-intensity varroasis (1-3 Varroa mites per bee) had no significant impact on the production of energy which is derived mainly from carbohydrates. Our findings are consistent with the above observations. Carbohydrate metabolism in newly-emerged bees was not significantly different between $\mathrm{C}$ and AA colonies. Those results corroborate our previous findings relating healthy brood (Farjan et al., 2015). Vitamin $\mathrm{C}$ supplementation in both healthy and infested capped brood (Table 2) did not induce significant changes in total carbohydrate content relative to the control group (Figure 1A).

Table 2. Influence of varroasis and supplementation of diet with vitamin $\mathrm{C}$ on carbohydrates concentration and activity enzymes of newly emerged honeybee workers (mean \pm S.D)

\begin{tabular}{|c|c|c|c|}
\hline \multirow{3}{*}{ Qualities measured } & \multicolumn{3}{|c|}{ Group } \\
\hline & \multirow{2}{*}{ Non-infested ${ }^{\#}$} & \multicolumn{2}{|c|}{ Infested with $V$. destructor } \\
\hline & & $\mathbf{C}$ & $\mathbf{A A}$ \\
\hline Total sugar content $(\mathrm{mg} / 100 \mathrm{mg})$ & $2.23 \pm 0.23$ & $5.07 \pm 4.46^{(-)}$ & $2.36 \pm 0.40$ \\
\hline Glycogen (mg/100 mg) & $3.04 \pm 0.06$ & $2.86 \pm 0.15$ & $3.05 \pm 0.11^{\mathrm{a}}$ \\
\hline Fructose (mg/100 mg) & $0.72 \pm 0.05$ & $0.64 \pm 0.01$ & $0.54 \pm 0.02^{\mathrm{a}}$ \\
\hline Glucose $(\mu \mathrm{g} / 100 \mathrm{mg})$ & $37.13 \pm 31.4$ & $76.15 \pm 60.12^{(-)}$ & $20.36 \pm 8.66^{(-)}$ \\
\hline Trehalose (mg/100 mg) & $0.70 \pm 0.18$ & $0.93 \pm 0.04$ & $0,92 \pm 0.07^{\mathrm{a}}$ \\
\hline A-amylase $(\mu \mathrm{g}$ starch $/ \mathrm{mg})$ & $5.28 \pm 1.55$ & $3.22 \pm 0.22$ & $5.35 \pm 0.05^{\mathrm{a}}$ \\
\hline Glucoamylase ( $\mu$ g glucose/mg) & $5.41 \pm 0.56$ & $0.01 \pm 0.001$ & $2.13 \pm 0.42^{\mathrm{a}}$ \\
\hline Trehalase ( $\mu$ g glucose/mg) & $17.78 \pm 1.85$ & $7.95 \pm 1.40$ & $9.24 \pm 0.78^{\mathrm{a}}$ \\
\hline Maltase ( $\mu$ g glucose/mg) & $18.85 \pm 8.55$ & $12.15 \pm 7.49^{(-)}$ & $14.0 \pm 3.65^{\mathrm{a}}$ \\
\hline Sucrase $(\mu \mathrm{g}$ glucose $/ \mathrm{mg})$ & $11.44 \pm 2.55$ & $14.05 \pm 4.95$ & $12.67 \pm 2.30$ \\
\hline
\end{tabular}

Note. ${ }^{a}$ letter indicate significant differences between means of the $\mathrm{C}$ and AA groups based on One-way ANOVA( $\mathrm{p} \leq 0.05)$ with Tukey's test for features with normal distribution(Shapiro-Wilk's test) and with Kruskal-Wallis's test for features with abnormal distribution (-) (Shapiro-Wilk's test).

Source: Data from Farjan et al. (2015).

It should be noted, however, that in the final stages of development, glycogen and trehalose levels were significantly higher in newly emerged infested workers in group AA than in group C (Figure 1B). The increase in glycogen and trehalose concentrations was observed despite a general increase in the activity of sugar-degrading enzymes during that period (Figures $1 \mathrm{~B}$ and $3 \mathrm{~A}$ ). The fact that AA-workers presented both an increased activity of amylases and reduced titers of glucose at the same time seems to suggest that glucose released from glycogen by enzymes was more rapidly metabolized by this group than control bees. The last stage of brood development is an important period in the life cycle of bees because insects become active immediately after hatching, and the accumulated glycogen and trehalose reserves are the main sources of energy until young bees begin to feed (Winston, 1987).

Studies of trehalose metabolism in other parasite-host relationships demonstrated that trehalose concentrations in infested hosts were higher than in uninfested insects. The above was reported in Heliotis virescens (Lepidoptera) infested with Microplitis croceipes or Campoletis sonorensis and in Manduca sexta infested with Cotesia congregate (Dalhman \& Vinson, 1975; Thompson et al., 2005). Similar observations were made in A. mellifera drones infested with $V$. destructor (Żółtowska et al., 2007). In newly emerged worker bees from group C trehalose concentrations was determined at $0.93 \pm 0.04 \mathrm{mg} / 100 \mathrm{mg} \mathrm{BW}$ in infested bees and $0.70 \pm 0.18 \mathrm{mg} / 100$ mg BW in uninfested bees (see Farjan et al., 2015). Moreover, trehalose level were significantly higher in infested workers from group AA than in group $\mathrm{C}$ bees (Figure 1B). Vitamin $\mathrm{C}$ supplementation tended to increase the trehalose content in healthy bees, but the differences between group AA and group $\mathrm{C}$ were not statistically significant (Farjan et al., 2015). Newly emerged infested workers in group AA were characterized by significantly higher body weights and higher concentrations of glycogen and trehalose, which indicates that they were in better health than control group bees. The above was confirmed by higher vigor in newly hatched 
workers from group AA. Maintenance of good health is very important for wintering bees, in infested colonies where winter losses are usually very high (Boecking \& Genersch, 2008; Van der Zee et al., 2012; Lichtenberg-Kraag, 2014).

The high and relatively constant levels of fructose, accompanied by very low levels of glucose and the near absence of sucrose in the carbohydrate pool of the brood and newly hatched workers, which were observed in this experiment and in our previous study of an uninfested brood (Farjan et al., 2015) remain unexplained. The above could be attributed to the lack of or low activity of enzymes that initiate fructose metabolism in the brood. Stored fructose can be used by bees immediately after hatching. Lower fructose levels in older workers could, at least partly, validate this hypothesis (Blatt \& Roces, 2001). Further research is needed to elucidate those mechanisms.

In this experiment and in our previous study of an uninfested worker brood (Farjan et al., 2015), the supplementation of bee diets with vitamin $\mathrm{C}$ had no significant effect on disaccharidases activity in successive stages of insect development. In infested bees, disaccharidases activity was significantly higher in newly emerged workers than in pupae. A particularly dynamic increase was noted in the activity of sucrase (Figure 3C), an enzyme that degrades sucrose in bee food (Lichtenberg-Kraag, 2014). The above observations and the significantly higher activity of both amylases in group AA imagines indicate that dietary vitamin C promotes effective carbohydrate degradation in the enzymatic system of bees (Ohashi et al., 1999).

\section{Conclusions}

The results of this experiment and previous studies indicate that vitamin $C$ supplementation delivers health benefits for wintering bees in colonies infested with varroasis. We analyzed the effect of vitamin $\mathrm{C}$ supplementation on carbohydrate metabolism in a developing brood of honey bee workers. Total carbohydrate content and the concentrations of glycogen, trehalose, fructose, and glucose were estimated. The correlations between sugar content and the activity of the main carbohydrate hydrolases - $\alpha$-amylase, glucoamylase, trehalase, maltase, and sucrase - were discussed. The vitamin C supplementation exerted a positive effect by significantly increasing glycogen and trehalose concentrations in newly emerged workers. Vitamin $\mathrm{C}$ did not induce significant changes in the developmental profile of carbohydrate degrading enzymes, excluding newly emerged workers where the activity of both amylases and trehalase was higher than in the control group. The increase in $\alpha$-glycosidase activity in the final stages of brood development might promote independent feeding in worker bees and more effectively prepares bees from the ascorbic acid supplemented group for the role of nurse bees in the colony. Newly emerged individuals from group supplemented with vitamin $\mathrm{C}$ were characterized by higher body weights. The prevalence and severity of infestation were reduced in colonies receiving vitamin $\mathrm{C}$.

Vitamin C exerted a positive influence on carbohydrate metabolism, although its effects were less spectacular than those noted in antioxidant systems. Our results suggest that winter diet of honey bees should be supplemented with vitamin $\mathrm{C}$ which enhances physiological parameters in both healthy and infested bee colonies and thus increase the condition of apiaries and support the larger crops.

\section{Acknowledgements}

The authors wish to express their gratitude to Jacek Nowakowski, PhD for providing advice on some of the statistical analysis of the results.

\section{References}

Andi, M. A., \& Ahmadi, A. (2014). Influence of vitamin C in sugar syrup on brood area, colony population, body weight and protein in honey bees. International Journal of Bioscience, 4, 32-36.

Benzzie, F. F. (2003). Evolution of dietary antioxidants. Comparative Biochemistry and Physiology, 136, 113-26. https://doi.org/10.1016/S1095-6433(02)00368-9

Black, J. (2006). Honey bee nutrition. Review of research and practices. A Report for Rural Industries Research and Developmental Corporation (p. 67). Australian Government, RIRDC Publication.

Blatt, J., \& Roces, F. (2001). Hemolymph sugars level in foraging honey bees (Apis mellifera carnica) dependence of metabolic rate and in vivo measurement of maximal rates of trehalose synthesis. Journal of Experimental Biology, 204, 2709-16.

Boecking, O., \& Genersch, E. (2008). Varroasis-The ongoing crisis in bee keeping. Journal für Verbraucherschutz und Lebensmittelsicherheit, 3, 221-8. https://doi.org/10.1007/s00003-008-0331-y 
Bowen-Walker, P. L., \& Gunn, A. (2001). The effect of the ectoparasitic mite, Varroa destructor on adult worker honeybee (Apis mellifera) emergence weights, water, protein, carbohydrate, and lipid levels. Entomologia Experimentalis et Applicata, 101, 207-17. https://doi.org/10.1046/j.1570-7458.2001.00905.x

Bradford, M. M. (1976). A rapid and sensitive method for quantitation of microgram quantities of protein utilizing the principle of protein-dye-binding. Analytical Biochemistry, 72, 248-54. https://doi.org/10.1016/ 0003-2697(76)90527-3

Briggs, M. H. (1962). Some aspects of the metabolism of ascorbic acid in insects. Comparative Biochemistry and Physiology, 5, 241-253. https://doi.org/10.1016/0010-406X(62)90054-3

Brodschneider, R., \& Crailsheim, K. (2010). Nutrition and health in honey bees. Apidologie, 41, $278-94$. https://doi.org/10.1051/apido/2010012

Burgett, M., Rucker, R. R., \& Thurman, W. N. (2004). Economics and honey bee pollination markets. The American Bee Journal, 144, 269-71.

Caraway, W. T. (1959). A stable starch substrate for the determination of amylase in serum and other body fluids. American Journal of Clinical Pathology, 32, 97-9. https://doi.org/10.1093/ajcp/32.1_ts.97

Contzen, C., Garedew, A., Lamprecht, I., \& Schmolz, E. (2004). Calorimetrical and biochemical investigations on the influence of the parasitic mite Varroa destructor on the development of the honeybee brood. Thermochimica Acta, 415, 115-21. https://doi.org/10.1016/j.tca.2003.06.006

Cornman, R. C., Tarpy, D. R., Chen, Y., Jeffreys, L., Lopez, D., Pettis, J. S., .. Evans, J. D. (2012). Pathogen Webs in Collapsing Honey Bee Colonies. PLoS ONE, 7, e43562. https://doi.org/10.1371/journal.pone. 0043562

Dahlqvist, A. (1968). Assay of intestinal disaccharidases. Analytical Biochemistry, 22, 99-107. https://doi.org/ 10.1016/0003-2697(68)90263-7

Dainat, B., Evans, J. D., Chen, Y. P., Gauthier, L., \& Neumanna, P. (2012). Dead or Alive: Deformed Wing Virus and Varroa destructor Reduce the Life Span of Winter Honeybees. Applied Environmental Microbiology, 8, 981-987. https://doi.org/10.1128/AEM.06537-11

Dalhman, D. L., \& Vinson, S. B. (1975). Trehalose and glucose levels in the hemolymph of Heliotthis virescens paratized by Microplitis croceipes or Cardiochile snigriceps. Comparative Biochemistry and Physiology B, 52, 465-8. https://doi.org/10.1016/0305-0491(75)90219-9

Duay, P. D., De Jong, D., \& Engels, W. (2003). Weight loss in drone pupae (Apis mellifera) multiply infested by Varroa destructor mites. Apidologie, 34, 61-65. https://doi.org/10.1051/apido:2002052

Farjan, M., Dmitryjuk, M., Lipiński, Z., Łopieńska-Biernat, E., \& Żółtowska, K. (2012). Supplementation of the honey bee diet with vitamin $\mathrm{C}$ : The effect on the antioxidative system of Apis mellifera carnica brood at different stages. Journal of Apicultural Research, 51, 263-70. https://doi.org/10.3896/IBRA.1.51.3.07

Farjan, M., Łopieńska-Biernat, E., Lipiński, Z., Dmitryjuk, M., \& Żółtowska, K. (2014). Supplementing with vitamin $\mathrm{C}$ the diet of honey bees (Apis mellifera carnica) parasitized with Varroa destructor: effects on antioxidative status. Parasitology, 141, 770-6. https://doi.org/10.1017/S0031182013002126

Farjan, M., Żółtowska, K., Lipiński, Z., Łopieńska-Biernat, E., \& Dmitryjuk, M. (2015). The effect of dietary vitamin $\mathrm{C}$ on carbohydrate concentrations and hydrolase activity during the development of honey bee worker brood. Journal of Apicultural Science, 59, 127-38. https://doi.org/10.1515/jas-2015-0001

Francis, R. M., Nielsen, S. L., \& Kryger, P. (2013). Varroa-virus interaction in collapsing honey bee colonies. PLoS ONE, 8, e57540. https://doi.org/10.1371/journal.pone.0057540

Glavinic, U., Stankovic, B., Draskovic, V., Stevanovic, J., Petrovic, T., Lakic, N., \& Stanimirovic, Z. (2017). Dietary amino acid and vitamin complex protects honey bee from immunosuppression caused by Nosema ceranae. PLoS ONE, 12(11), e0187726. https://doi.org/10.1371/journal.pone.0187726

Gliński, Z., \& Jarosz, J. (1988). Varroa jacobsoni invasion and the level of cell-free immunity in upright larvae of the worker honey bee Apis mellifera. Folia Veterinaria, 32, 39-50.

Gliński, Z., \& Jarosz, J. (1992). Varroa jacobsoni as a carrier of bacterial infections to a recipient bee host. Apidologie, 23, 25-31. https://doi.org/10.1051/apido:19920103

Harz, M., Müller, F., \& Rademacher, E. (2010). Organic acids: Acute toxicity on Apis mellifera and recovery in the haemolymph. Journal of Apicultural Research, 49, 95-6. https://doi.org/10.3896/IBRA.1.49.1.14 
Herbert, E. W., Vanderslice, J. T., \& Higgs, D. J. (1985). Effect of dietary vitamin C levels on the rate of brood production of free-flying and confined colonies of honey bees. Apidologie, 16, 385-94. https://doi.org/ 10.1051/apido:19850403

Hrassing, N., \& Crailsheim, K. (2005). Differences in drone and worker physiology in honeybees (Apis mellifera). Apidologie, 36, 255-70. https://doi.org/10.1051/apido:2005015

Jay, C. S. (1963). Colour changes in honey bee pupae. Bee World, 43, 119-22. https://doi.org/10.1080/ 0005772X.1962.11096960

Jay, C. S. (1964). The development of honeybees in their cells. Journal of Apiculture Research, 2, 117-34. https://doi.org/10.1080/00218839.1963.11100072

Kramer, K. J., \& Seib, P. A. (1982). Ascorbic acid and the growth and development of insects. In P. A. Seib, \& B. M. Tolbert (Eds.), Ascorbic acid: Chemistry, metabolism and uses (Advances in Chemistry Series No 200, pp. 273-91). Washington: American Chemical Society.

Kuster, R. D., Humberto, F., Boncristiani, H. F., \& Rueppell, O. (2014). Immunogene and viral transcript dynamics during parasitic Varroa destructor mite infection of developing honey bee (Apis mellifera) pupae. Journal of Experimental Biology, 217, 1710-18. https://doi.org/10.1242/jeb.097766

Lichtenberg-Kraag, B. (2014). Evidence for correlation between invertase activity and sucrose content during the ripening process of honey. Journal of Apicultural Research, 53, 364-73. https://doi.org/10.3896/IBRA.1

Lipiński, Z., \& Żółtowska, K. (2005). Preliminary evidence associating oxidative stress in honey bee drone brood with Varroa destructor. Journal of Apicultural Research, 44, 126-8. https://doi.org/10.1080/ 00218839.2005 .11101163

Loper, G. M., Standifer, L. N., Thomson, M. J., \& Gilliam, M. (1980). Biochemistry and microbiology of bee-collected almond (Prunus dulcius) pollen and bee bread. Apidologie, 11, 63-73. https://doi.org/10.1051/ apido: 19800108

Maharaj, R. (2011). Global trends in insecticide resistance and impact on disease vector control measures. Open Access Insect Physiology, 3, 27-33. https://doi.org/10.2147/OAIP.S8620

Mishra, V. (2007). Oxidative stress and role of antioxidant supplementation in critical illness. Clinical Laboratory, 53, 199-209.

Morse, E. E. (1947). Anthrone in estimating low concentration of sugar. Analytical Chemistry, 199, 1012-13. https://doi.org/10.1021/ac60012a021

Ohashi, K., Natori, S., \& Kubo, T. (1999). Expression of amylase and glucose oxidase in the hypopharyngeal gland with an age-dependent role change of the worker honeybee (Apis mellifera L.). European Journal of Biochemistry, 265, 127-33. https://doi.org/10.1046/j.1432-1327.1999.00696.x

Ostiguy, N., \& Eitzer, B. (2014). Overwintered brood comb honey: Colony exposure to pesticide residues. Journal of Apicultural Research, 53, 413-21. https://doi.org/10.3896/IBRA.1.53.3.10

Rosenkranz, P., Aumeier, P., \& Ziegelmann, B. (2010). Biology and control of Varroa destructor. Journal of Insect Pathology, 103, S96-S119. https://doi.org/10.1016/j.jip.2009.07.016

Sammataro, D., Gerson, U., \& Needham, G. (2000). Parasitic mites of honey bees, life history, implications, and impact. Annual Review of Entomology, 45, 519-48. https://doi.org/10.1146/annurev.ento.45.1.519

Sölling, H., \& Essman, V. (1975). A sensitive method of glycogen determination in the presence of interfering substances utilizing the filter-paper technique. Analytical Biochemistry, 68, 664-8. https://doi.org/10.1016/ 0003-2697(75)90667-3

Standifer, L. N. (1980). Honey bee nutrition and supplemental feeding. Beekeeping in the United States Agriculture (pp. 39-45). Agriculture Handbook, USDA.

Thompson, S. N., Redak, R. A., \& Wang, L.-W. (2005). Host nutrition determines blood nutrient composition and mediates parasite developmental success: Manducasexta L. parasitized by Cotesiacongregata (Say). Journal of Experimental Biology, 208, 625-35. https://doi.org/10.1242/jeb.01403

Underwood, R. M., \& Currie, R. W. (2003). The effects of temperature and dose of formic acid on treatment efficacy against Varroa destructor (Acari: Varroidae), a parasite of Apis mellifera (Hymenoptera: Apidae). Experimental \& Applied Acarology, 29, 303-13. https://doi.org/10.1023/A:1025892906393 
Van der Zee, R., Gray, A., Holzmann, C., Pisa, L., Brodschneider, R., Chlebo, R., ... Wilkins, S. (2013). Standard survey methods for estimating colony losses and explanatory risk factors in Apis mellifera. Journal of Apicultural Research, 52, 1-36. https://doi.org/10.3896/IBRA.1.52.4.18

Van der Zee, R., Pisa, L., Andonov, S., Brodschneider, R., Charrière, J.-D., Chlebo, R., ... Wilkins, S. (2012). Managed honey bee colony losses in Canada, China, Europe, Israel and Turkey, for the winters of 2008-9 and 2009-10. Journal of Apicultural Research, 51, 100-114. https://doi.org/10.3896/IBRA.1.51.1.12

Van Engelsdorp, D., \& Meixner, M. D. (2010). A historical review of managed honey bee populations in Europe and the United States and the factors that may affect them. Journal of Invertebrate Pathology, 103, S80-S95. https://doi.org/10.1016/j.jip.2009.06.011

Winston, M. L. (1987). The biology of the honey bee (p. 281). Harvard University Press, Cambridge.

Wu, J. Y., Anelli, C. M., \& Sheppard, W. S. (2011). Sub-lethal effects of pesticide residues in brood comb on worker honey bee (Apis mellifera) development and longevity. PLOS ONE, 6, e14720. https://doi.org/ 10.1371/journal.pone.0014720

Yang, X., \& Cox-Foster, D. L. (2005). Impact of an ectoparasite on the immunity and pathology of an invertebrate: Evidence for host immunosuppression and viral amplification. PNAS USA, 102, 7470-5. https://doi.org/10.1073/pnas.0501860102

Żółtowska, K., Lipiński, Z., \& Dmitryjuk, M. (2005). The total protein content, protein fractions and proteases activity of drone prepupae of Apis mellifera due to varroasis. Wiadomości Parazytologiczne, 51, 43-7.

Żółtowska, K., Lipiński, Z., \& Farjan, M. (2007). Activity of selected hydrolases in ontogeny of drone Apis mellifera carnica. Journal of Apicultural Science, 51, 95-100.

Żółtowska, K., Lipiński, Z., Dmitryjuk, M., \& Myszka, A. (2005). Sugar content, trehalase activity and trehalose level in drone prepupae of Apis mellifera carnica parasitized with Varroa. Journal of Apicultural Science, 49, 61-6.

\section{Copyrights}

Copyright for this article is retained by the author(s), with first publication rights granted to the journal.

This is an open-access article distributed under the terms and conditions of the Creative Commons Attribution license (http://creativecommons.org/licenses/by/4.0/). 